\title{
Hepatoprotective and antioxidant activity of Lannea coromandelica Linn. on thioacetamide induced hepatotoxicity in rats
}

\author{
V. Srinivasa Rao ${ }^{1}$, John Wilkin Einstein ${ }^{1}$, Kuntal Das ${ }^{2, *}$ \\ ${ }^{1}$ St. John's Pharmacy College, \#6, II Main, Vijaya Nagar, Bangalore - 560104, India \\ ${ }^{2}$ Krupanidhi College of Pharmacy, \# 12/1, Chikka Bellandur, Carmelaram Post, \\ Varthur Hobli, Bangalore - 560035, India \\ Mob: +919632542846 \\ *E-mail address: drkkdsd@gmail.com
}

\begin{abstract}
Hepatoprotective and antioxidant activity of Lannea coromandelica bark extract (LCBE) was investigated on thioacetamide induced hepatotoxicity in rats. Hepatotoxicity was induced by thioacetamide (TAA) administration (100 mg/kg. s.c). LCBE at different doses (400 and $200 \mathrm{mg} / \mathrm{kg}$ ) were administered orally to male wistar rats. Thioacetamide caused elevation of serum concentration of AST, ALT, ALP, serum bilirubin and also reduced serum concentration of total protein, albumin, sodium, potassium in animals as compared to control $(\mathrm{p}<0.05)$ but LCBE treated rats showed maximum reduction of AST [(138 \pm 5.1$) \mathrm{IU} / \mathrm{L}]$, ALT [(71 \pm 2.7$) \mathrm{IU} / \mathrm{L}]$, ALP $[(140 \pm 1.9) \mathrm{IU} / \mathrm{L}]$ with the high dose $(400 \mathrm{mg} / \mathrm{kg} \mathrm{bw})$ of combined aqueous and alcoholic bark extract. Whereas, serum bilurubin, cholesterol, sugar and LDH content were varied with the treatments but showed higher with the only ethanolic extract at dose of $400 \mathrm{mg} / \mathrm{kg}$. The $\mathrm{IC}_{50}$ value was observed as $(83.28 \pm 2.12) \mu \mathrm{g} / \mathrm{mL}$, for DPPH radical scavenging activity. Result concluded that ethanolic extract and combined aqueous and alcoholic bark extract of $L$. coromandelica showed a potential hepatoprotective and antioxidant activities might be due to the presence of phenolic groups, terpenoids and alkaloids.
\end{abstract}

Keywords: Antioxidant activity; biochemical parameters; hepatoprotective; Lannea coromandelica; thioacetamide

\section{INTRODUCTION}

Liver is the primary site for intense various metabolism and excretion. It involves with the various biochemical pathways to growth, fight against diseases, energy and nutrient supply and reproduction [1]. Liver produces and secretes bile, it also produces prothrombin and fibrinogen, both blood clotting factors, and heparin, a mucopolysaccharide sulfuric acid ester that helps keep blood from clotting within the circulatory system. The liver converts sugar into glycogen [2]. Liver diseases have become one of the major causes of morbidity and mortality in man and animals all over globe and hepatotoxicity due to drugs appears to be the most common contributing factors. Among the many diseases that can affect the liver the most common is 'viral hepatitis' and it can also caused by drugs, bacteria, mushrooms, parasites like amoebas. About 20,000 deaths found every year due to liver disorders [3]. One 
in twelve persons suffers from some form of chronic liver disease worldwide, while more than 50 million people have advanced chronic liver disease in India. The most common indication for a liver transplant is advanced chronic liver disease, including viral diseases such as Hepatitis B and C, alcohol abuse and acute liver failure. In vivo studies make it difficult to distinguish the primary effects of compounds to those induced secondarily because liver functions are under the influence of various endogenous and exogenous factors, which result in complex interactions with other organs. Moreover, most of our understanding regarding liver injury induced by drugs and other chemicals at a mechanistic level remains confined to experimental models. Since the rates and the routes of drug metabolism can vary greatly, particularly when comparisons involved laboratory animals and man, data obtained in animals cannot be extrapolated with a certainty to the human situation. These drawbacks of in vivo animal studies explain why many investigators have turned to simpler experimental models for studying drug metabolism and response of the organ or liver cells to potentially toxic agents [4].

There is a huge patronage of herbal products around the world as an alternative to synthetic drugs and these medicinal plants have immensely contributed to the development of safe human health and welfare [5]. The use of medicinal plants for alleviating diseases is growing day by day around the world especially in Asian countries like India. Conventional drugs used in the treatment of liver diseases are sometimes inadequate and can have serious side effects; therefore it is necessary to search for alternative drugs for the treatment of liver disease in order to replace currently used drugs of doubtful efficacy and safety [6]. Moreover, plants are the source of versatile chemical compounds. The costs of the drugs are also increasing significantly. Hence, the use of traditional medicinal plants, as a basis for the maintenance of good health, has been widely observed. About 100 Indian medicinal plants belonging to 40 families are used for herbal formulation [7]. Oflate Lannea coromandelica is a plant (belongs to the family Anacardiaceae) which claims as astringent and stomachic (bark extract), cures sprains, bruises, skin eruptions, heart diseases, dysentery and mouth sores. Decoction of the bark is used for toothache. Its bark is also useful in impotency. Scrapped bark is chewed for 2-3 days to cure glossitis. Boiled leaves are applied as a fomentation for local swelling and pains etc [8]. Its hepatoprotective activity was also reported traditionally due to presence of dihydroflavonols in the stem bark [9] and also due to presence of some important chemical constituents viz. Terpenoids, Polyphenols, Flavonoids, Kaemferol, Quercetin, and further it shows antioxidant properties [10] but still not been scientifically investigated for its hepato-protective activity from Indian origin. Hence the present study was designed to investigate the use of LCBE as a hepatoprotective and antioxidative agent in thioacetamide induced hepatic damages in rats.

\section{MATERIALS AND METHODS}

\section{1. Collection of Plant material}

The plant bark material was collected in the month of August -September, 2012 from Botanical garden of Kolkata, West Bengal, India. The plant has been identified and authenticated by Dr. T. N. Shivananda, Senior Scientist, Indian Institute of Horticultural Research, Bangalore, India, Department of Medicinal and Aromatic Plant. The plant parts specimen was submitted as herbarium with voucher specimen no 211/ Pharmacog/ Srinivasa/07. 


\section{2. Preparation of Extracts}

The bark was shade dried for 20 days and coarse powder prepared with hammer mill and stored at room temperature in a sealed plastic covers to avoid moisture absorption. Separately about $250 \mathrm{~g}$ of the powdered bark was extracted with aqueous, $70 \%$ ethanol and with the mixture of equal ratio of aqueous and ethanol solvent by maceration method. All the extracts were filtered separately, evaporated with the rotary flash evaporator at $40{ }^{\circ} \mathrm{C}$ and stored at refrigeration condition for further investigation. The yield of extracts was calculated.

\section{3. Phytochemical Screening}

The freshly prepared crude extracts (LCBE) were qualitatively tested as described by Kokate (1996) [11] for the presence of Alkaloids, Flavonoids, Steroids, Terpenoids, Saponins, Tannins and Cardiac glycosides.

\section{4. Chemicals}

DPPH (1,1-diphenyl, 2-picrylhydrazyl) was obtained from Sigma Chemical Co. USA; Gallic acid was from SD Fine Chem. Ltd. India, Standard drug Silymarin was obtained from Sigma-aldrich chemcal Pvt. Ltd., Bangalore. Thioacetamide, hepatotoxin was obtained from Sigma-aldrich chemical Pvt. Ltd., Bangalore. Tween 80 was obtained from Nice chemicals Bangalore. Estimation Kits for AST, ALT, ALP, SBR, T.P, DIR, Sodium, Potassium, SPAN diagnostics kits was used.

\section{5. Selection of Animals}

Healthy adult Wistar rats weighing 180-200 was obtained from the Central Animal Facilities of St. John's Pharmacy College, Bangalore. The animals were housed in well ventilated cage and animals had 12 hours day and night schedule with temperature between $28 \pm 2{ }^{\circ} \mathrm{C}$. The animals were housed in large spacious hygienic cages during the course of the experimental period. The animals were allowed free access to standard laboratory pellets and drinking water ad libitum. The study protocol was approved by Institutional Animal Ethics Committee (IAEC) on 17/03/2012 (Ref No. Col/07/CPCSEA), St. John's Pharmacy College, Bangalore, India.

\section{6. Toxicity studies}

Swiss albino mice of either sex weighting between 30 to $40 \mathrm{gm}$ were used for acute oral toxicity study and the method was followed as per OECD Guidelines No. 423. The animals were fasted overnight prior to the experimental procedure. All the three extracts i.e., Aqueous (LCAE), Alcoholic (LCEE), and Mixture (50\% Alcohol + $50 \%$ Aqueous) (LCAE+LCEE) of LCBE was given in various doses $(5,50,300$, and $2000 \mathrm{mg} / \mathrm{kg}$ b.w.) by gastric incubation with a syringe. After administration of the extract, the animal were observed continuously for the first two hours and at 24 hours to detect changes in behavioral responses and also for tremors, convulsion, salivation, diarrhoea, lethargy, sleep, coma and also were monitored up to 14 days for the toxic symptoms and mortality. The initial dose level is selected on the basis of a sighting study as the dose expected to produce some signs of toxicity without causing severe toxic effects or mortality [12]. $\mathrm{LD}_{50}$ is expressed in terms of $\mathrm{mg} / \mathrm{kg}$.

\section{7. Evaluation of hepatoprotective activity}

Thioacetamide induced hepatotoxicity in rats model was used for evaluation of hepatoprotective activity for the plant extracts. Animals were divided into nine groups consisting of 
six rats in each group. The animals of group I served as control (vehicle) were given only Saline ( $2 \mathrm{ml} / \mathrm{kg}$ b.w., per orally) for seven days. The animals of group II were administered with thioacetamide (TAA, $100 \mathrm{mg} / \mathrm{kg} \mathrm{b}$. w., s.c.) as a $2 \% \mathrm{w} / \mathrm{v}$ solution in water for injection on day 1 st and then normal saline for 21 days. The animals of group III were administered with TAA $(100 \mathrm{mg} / \mathrm{kg} \mathrm{b.} \mathrm{w.,} \mathrm{s.c.)} \mathrm{as} \mathrm{a} 2 \% \mathrm{w} / \mathrm{v}$ solution in water for injection on day $1 \mathrm{st}$ and then silymarin $(25 \mathrm{mg} / \mathrm{kg}$ per day, p. o.) for 21 days. Group IV and V animals were administered with TAA $(100 \mathrm{mg} / \mathrm{kg}$ b .w., s.c.) as a $2 \% \mathrm{w} / \mathrm{v}$ solution in water for injection on day $1 \mathrm{st}$ and then LCEE (400 mg/kg and $200 \mathrm{mg} / \mathrm{kg}$ respectively) for 21 days. Group VI and VII animals were administered with TAA $(100 \mathrm{mg} / \mathrm{kg} \mathrm{b}$.w., s.c.) as a $2 \% \mathrm{w} / \mathrm{v}$ solution in water for injection on day $1 \mathrm{st}$ and then LCAE $(400 \mathrm{mg} / \mathrm{kg}$ and $200 \mathrm{mg} / \mathrm{kg}$ respectively) for 21 days and finally for group VIII and IX animals were administered with combined extracts i.e TAA $(100 \mathrm{mg} / \mathrm{kg} \mathrm{b}$.w., s.c.) as a $2 \% \mathrm{w} / \mathrm{v}$ solution in water for injection on day $1 \mathrm{st}$ and then LCAE + LCEE ( $400 \mathrm{mg} / \mathrm{kg}$ and $200 \mathrm{mg} / \mathrm{kg}$ respectively) for 21 days. Rats of all the groups were anaesthetized by diethyl ether, $48 \mathrm{hr}$ after the TAA administration. The blood was collected from retro-orbital plexus. The blood was collected from rats were sacrificed and the liver was carefully dissected, cleaned for extraneous tissue, and fixed in $10 \%$ formalin for histopathological studies. The collected blood samples were immediately centrifuged at $2400 \mathrm{rpm}$ for 15 minutes. When serum clearly separated out, the serum was analyzed for AST, ALT, ALP, total bilirubin, direct bilurubin, total protein, serum albumin, serum sodium, serum potassium serum bilirubin levels using SPAN diagnostics reagent kits.

\section{8. In-vitro Antioxidant Activity}

DPPH method: Free radical scavenging activity of the different extracts of bark was determined by decrease in the absorbance of methanol solution of DPPH (2,2-Diphenyl-1picrylhydrazyl) [13]. Antioxidant activities of the different fractions were determined on the basis of their scavenging potential of the stable DPPH free radical. $2.0 \mathrm{ml}$ of various concentrations of each sample were mixed with $3.0 \mathrm{ml}$ of a DPPH methanol solution (20 $\mu \mathrm{g} / \mathrm{ml})$. After $30 \mathrm{~min}$ reaction period at room temperature in dark place, the absorbance was measured at $517 \mathrm{~nm}$ against methanol as blank by using a UV- visible spectrophotometer. Inhibition free radical DPPH in percent (I \%) was calculated as follows:

Percentage inhibition $(\mathrm{I} \%)=\left(1-\mathrm{A}_{\text {sample }} / \mathrm{A}_{\text {blank }}\right) \mathrm{X} 100$

$A_{\text {blank }}=$ Absorbance of the control reaction (containing all reagents except the test material). $\mathrm{A}_{\text {sample }}=$ Absorbance of the test sample.

Gallic acid was used as positive control. Tests carried out in triplicate and average value was taken. Extract concentration providing $50 \%$ inhibition $\left(\mathrm{IC}_{50}\right)$ was calculated from the graph plotted inhibition percentage against extract concentration

\section{8. 1. Statistical analysis}

The data obtained by the various parameters was statistically evaluated by one way analysis of variance (ANOVA) followed by Turkey multiple comparisons test (Graph Pad software Inc., Version 5.0.0). Where $\mathrm{n}=6$ mean values \pm SEM were calculated for each parameter. Level of significance was kept at $p<0.05$. In case of antioxidant study the values were triplicated and the results were tabulated \pm SD (Standard deviation). 


\section{RESULTS}

\section{1. Phytochemical study}

Initial yield of the individual extracts were determined as $2.7 \% \mathrm{w} / \mathrm{w}$ (LCAE), $3.4 \%$ $\mathrm{w} / \mathrm{w}$ (LCEE) and $3.8 \% \mathrm{w} / \mathrm{w}$ (LCAE + LCEE) and further phytochemical screenings of the crude LCBE were performed and it revealed the presence of flavonoids, sugar, protein, triterpenoids, alkaloids, tannins and phenols.

\section{2. Acute oral toxicity}

Acute oral toxicity was carried out according to OECD guidelines. LCAE, LCEE and combination of LCAE and LCEE were safe up to $2000 \mathrm{mg} / \mathrm{kg}$ and were lethal at $5000 \mathrm{mg} / \mathrm{kg}$ dose. Hence the dose selected for study was $200 \mathrm{mg} / \mathrm{kg}$ as low dose and $400 \mathrm{mg} / \mathrm{kg}$ as high dose.

\section{3. Hepatoprotective activity}

The present studies were performed to assess the hepatoprotective activity in rats against TAA as hepatoprotective as hepatotoxins to prove its claims in folklore practice against liver disorders. The extent of hepatic damage is assessed by histological evalution and the levels of various biochemical parameters in circulation.

\section{3. 1. Effect of Lannea coromandelica extracts on serum biomarker enzymes in Thioacetamide induced hepatotoxicity}

Rat treated with thioacetamide developed a significant hepatic damage observed as elevated serum level of hepato specific enzymes like ALP, ALT, and AST when compared to the normal control. After treatment with silymarin and extracts in respective groups showed good protection against thioacetamide toxicity to liver. Dunnet comparison test indicates a significant reduction in elevated serum enzymes level with extract treated group to toxic control group. Combined LCAE and LCEE at a dose of $400 \mathrm{mg} / \mathrm{kg}$ showed the most protective effect in reducing the elevated serum enzyme level $(p<0.001)$ followed by LCEE at dose of $400 \mathrm{mg} / \mathrm{kg}$. than others whereas LCAE and LCEE in combination dose at 200 $\mathrm{mg} / \mathrm{kg}$ was not effective i.e $(\mathrm{p}>0.05)$ for ALP only (Table 1$)$.

Table 1. Effect of Lannea coromandelica extracts on serum biomarker enzymes in Thioacetamide induced hepatotoxicity.

\begin{tabular}{|c|c|c|c|}
\hline \multirow{2}{*}{ GROUPS } & \multicolumn{3}{|c|}{ BIOCHEMICAL PARAMETERS } \\
\cline { 2 - 4 } & ALP(IU/L) & ALT(IU/L) & AST(IU/L) \\
\hline Saline & $110 \pm 2.7$ & $59 \pm 1.3$ & $110 \pm 3.1$ \\
\hline TAA & $400 \pm 22$ & $190 \pm 2.9$ & $260 \pm 6.6$ \\
\hline Standard & $130 \pm 4.0^{* * *}$ & $95 \pm 4.5^{* * *}$ & $140 \pm 2.6^{* * *}$ \\
\hline LCEE $(400 \mathrm{mg} / \mathrm{kg})$ & $170 \pm 6.6^{* * *}$ & $75 \pm 5.3^{* * *}$ & $140 \pm 4.2^{* * *}$ \\
\hline
\end{tabular}




\begin{tabular}{|c|c|c|c|}
\hline LCEE $(200 \mathrm{mg} / \mathrm{kg})$ & $210 \pm 7.0^{* * *}$ & $120 \pm 9.4^{* * *}$ & $170 \pm 4.3^{* * *}$ \\
\hline LCAE $(400 \mathrm{mg} / \mathrm{kg})$ & $290 \pm 18^{* * *}$ & $120 \pm 11^{* * *}$ & $160 \pm 3.1^{* * *}$ \\
\hline LCAE $(200 \mathrm{mg} / \mathrm{kg})$ & $300 \pm 15^{* * *}$ & $87 \pm 3.7^{* * *}$ & $170 \pm 6.2^{* * *}$ \\
\hline LCAE+ LCEE $(400 \mathrm{mg} / \mathrm{kg})$ & $140 \pm 1.9^{* * *}$ & $71 \pm 2.7^{* * *}$ & $138 \pm 5.1^{* * *}$ \\
\hline LCAE + LCEE $(200 \mathrm{mg} / \mathrm{kg})$ & $450 \pm 32^{\mathrm{ns}}$ & $99 \pm 17^{* * *}$ & $180 \pm 16^{* * *}$ \\
\hline
\end{tabular}

Values are Mean \pm S.E.M. $(n=6)$; ONE way ANOVA followed by Dunnet comparisons test Significance values are $* * * \mathrm{p}<0.001, * * \mathrm{p}<0.01, * \mathrm{p}<0.05$ and $\mathrm{ns} \mathrm{p}>0.05$ TAA group vs all groups.

\section{4. Biochemical parameters}

\section{4. 1. Effect of Lannea coromandelica extracts on total protein, albumin and total bilirubin in Thioacetamide induced hepatotoxicity}

TAA treatment has considerably reduced the serum total protein and albumin levels. Treatment with silymarin and extracts showed significant increase in the total protein and albumin level as compared to the TAA groups. Alcoholic extract at a dose of $400 \mathrm{mg} / \mathrm{kg}$ showed significant increase in total protein and albumin level $(\mathrm{p}<0.001)$ followed by 200 $\mathrm{mg} / \mathrm{kg}(\mathrm{p}<0.001)$. Aqueous extracts at dose of $400 \mathrm{mg} / \mathrm{kg}$ and $200 \mathrm{mg} / \mathrm{kg}$ was equally effect at $(\mathrm{p}<0.001),(\mathrm{p}<0.001)$ respectively. LCAE + LCEE was also effective and showed the elevated serum enzyme level for dose of $400 \mathrm{mg} / \mathrm{kg}(\mathrm{p}<0.005)$ and $200 \mathrm{mg} / \mathrm{kg}(\mathrm{p}<0.001)$ respectively.

\section{4. 2. Effect of Lannea coromandelica extract on Total and Direct bilirubin in Thioacetamide induced hepatotoxicity}

Elevation of direct and total bilirubin level after administration of thioacetamide indicate its hepatotoxicity. Treatment with silymarin and extracts significantly reduced level of direct and total bilirubin level when compared to the toxic control indicating hepatoprotective effect of plant extracts. Alcoholic extracts was significantly effective among all the extract with $(\mathrm{p}<0.001)$, followed by LCAE and LCAE + LCEE at $(\mathrm{p}<0.01)$, $(\mathrm{p}<$ $0.001)$.

\section{4. 3. Effect of Lannea coromandelica extracts on sodium and potassium concentration in Thioacetamide induced hepatotoxicity}

Groups treated with thioacetamide developed a significant hepatic damage showing significant decrease in $\mathrm{Na}^{+}-\mathrm{K}^{+}$-ATPase activity compared to control Treatment with silymarin and extracts significantly reduced hepatic $\mathrm{Na}^{+}-\mathrm{K}^{+}-$ATPase activity, induced by thioacetamide intoxication Alcoholic and Aqueous extracts were equally effective with high significance of $(p<0.001)$ showing hepatoprotective activity, where as LCAE + LCEE extract was also effective with $(\mathrm{p}<0.001)$. Table 2 was depicted the summery of the biochemical parameters. 
Table 2. Effect of Lannea coromandelica extracts on serum parameters.

Total protein, Albumin, Bilirubin and ions.

\begin{tabular}{|c|c|c|c|c|c|c|}
\hline \multirow{3}{*}{ GROUPS } & \multicolumn{6}{|c|}{ BIOCHEMICAL PARAMETERS } \\
\hline & \multirow{2}{*}{$\begin{array}{l}\text { TOTAL } \\
\text { PROTEIN } \\
\text { g/dl }\end{array}$} & \multirow{2}{*}{$\begin{array}{l}\text { TOTAL } \\
\text { ALBUM } \\
\text { INE g/dl }\end{array}$} & \multicolumn{2}{|c|}{ SERUM BILIRUBIN g/dl } & \multirow{2}{*}{$\begin{array}{c}\text { SODIUM } \\
\mathrm{mEq} / \mathrm{L}\end{array}$} & \multirow{2}{*}{$\begin{array}{c}\text { POTASIUM } \\
\mathrm{mEq} / \mathrm{L}\end{array}$} \\
\hline & & & TOTAL & DIRECT & & \\
\hline Saline & $\begin{array}{c}0.52 \\
\pm 0.021\end{array}$ & $\begin{array}{c}5.0 \\
\pm 0.47\end{array}$ & $\begin{array}{c}0.52 \\
\pm 0.017\end{array}$ & $\begin{array}{c}0.039 \\
\pm 0.006\end{array}$ & $\begin{array}{c}144.5 \\
\pm 2.035\end{array}$ & $\begin{array}{c}6.0 \\
\pm 0.66\end{array}$ \\
\hline TAA & $\begin{array}{c}0.80 \\
\pm 0.03\end{array}$ & $\begin{array}{c}2.8 \\
\pm 0.24\end{array}$ & $\begin{array}{c}0.80 \\
\pm 0.026\end{array}$ & $\begin{array}{l}0.25 \pm \\
0.025\end{array}$ & $\begin{array}{c}83.63 \\
\pm 3.688\end{array}$ & $\begin{array}{c}2.5 \\
\pm 0.11\end{array}$ \\
\hline Standard & $\begin{array}{c}0.34 \\
\pm 0.013^{* * *}\end{array}$ & $\begin{array}{c}4.0 \\
\pm 0.13^{* * *}\end{array}$ & $\begin{array}{c}0.34 \\
\pm 0.013^{* * *}\end{array}$ & $\begin{array}{c}0.053 \\
\pm 0.008^{* * *}\end{array}$ & $\begin{array}{l}132.0 \\
\pm 1.89^{* * *}\end{array}$ & $\begin{array}{c}4.6 \\
\pm 0.19^{* * * *}\end{array}$ \\
\hline $\begin{array}{c}\text { LCEE } \\
(400 \mathrm{mg} / \mathrm{kg})\end{array}$ & $\begin{array}{c}0.41 \\
\pm 0.015^{* * *}\end{array}$ & $\begin{array}{c}3.9 \\
\pm 0.25^{* *}\end{array}$ & $\begin{array}{c}0.41 \\
\pm 0.015^{* * *}\end{array}$ & $\begin{array}{c}0.094 \\
\pm 0.019^{* * *}\end{array}$ & $\begin{array}{c}116.9 \\
\pm 2.89^{* * *}\end{array}$ & $\begin{array}{c}5.7 \\
\pm 0.25^{* * *}\end{array}$ \\
\hline $\begin{array}{c}\text { LCEE } \\
(200 \mathrm{mg} / \mathrm{kg})\end{array}$ & $\begin{array}{c}0.57 \\
\pm 0.018^{* * *}\end{array}$ & $\begin{array}{c}3.4 \\
\pm 0.13^{\mathrm{ns}}\end{array}$ & $\begin{array}{c}0.57 \\
\pm 0.018^{* * *}\end{array}$ & $\begin{array}{c}0.13 \\
\pm 0.023^{* *}\end{array}$ & $\begin{array}{c}101.0 \\
\pm 5.12^{*}\end{array}$ & $\begin{array}{c}3.8 \\
\pm 0.18^{* *}\end{array}$ \\
\hline $\begin{array}{c}\text { LCAE } \\
(400 \mathrm{mg} / \mathrm{kg})\end{array}$ & $\begin{array}{c}0.54 \\
\pm 0.029^{* * *}\end{array}$ & $\begin{array}{c}4.1 \\
\pm 0.15^{\text {*** }}\end{array}$ & $\begin{array}{c}0.54 \\
\pm 0.029^{* * *}\end{array}$ & $\begin{array}{c}0.12 \\
\pm 0.028^{* *}\end{array}$ & $\begin{array}{c}118.4 \\
\pm 4.23^{* *}\end{array}$ & $\begin{array}{c}3.8 \\
\pm 0.29^{* *}\end{array}$ \\
\hline $\begin{array}{c}\text { LCAE } \\
(200 \mathrm{mg} / \mathrm{kg})\end{array}$ & $\begin{array}{c}0.61 \\
\pm 0.015^{* * *}\end{array}$ & $\begin{array}{c}3.8 \\
\pm 0.12^{* *}\end{array}$ & $\begin{array}{c}0.61 \\
\pm 0.015^{* * *}\end{array}$ & $\begin{array}{c}0.11 \\
\pm 0.035^{* * *}\end{array}$ & $\begin{array}{c}94.38 \\
\pm 6.671^{\text {ns }}\end{array}$ & $\begin{array}{c}4.3 \\
\pm 0.35^{* * * *}\end{array}$ \\
\hline $\begin{array}{c}\text { LCAE + } \\
\text { LCEE } \\
(400 \mathrm{mg} / \mathrm{kg})\end{array}$ & $\begin{array}{c}0.51 \\
\pm 0.029^{* * *}\end{array}$ & $\begin{array}{c}4.5 \\
\pm 0.29^{\text {**** }}\end{array}$ & $\begin{array}{c}0.51 \\
\pm 0.029^{* * *}\end{array}$ & $\begin{array}{c}0.071 \\
\pm 0.009^{* * *}\end{array}$ & $\begin{aligned} & 111.3 \\
& \pm 2.39^{* * *} \\
&\end{aligned}$ & $\begin{array}{c}6.1 \\
\pm 0.26^{* * *}\end{array}$ \\
\hline $\begin{array}{c}\text { LCAE + } \\
\text { LCEE } \\
(200 \mathrm{mg} / \mathrm{kg})\end{array}$ & $\begin{array}{c}0.62 \\
\pm 0.030^{* * *}\end{array}$ & $\begin{array}{c}4.6 \\
\pm 0.25^{* * *}\end{array}$ & $\begin{array}{c}0.62 \\
\pm 0.030^{* * *}\end{array}$ & $\begin{array}{c}0.12 \\
\pm 0.024^{\text {*** }}\end{array}$ & $\begin{array}{l}120.6 \\
\pm 3.48^{* * *}\end{array}$ & $\begin{array}{c}6.3 \\
\pm 0.24^{* * *}\end{array}$ \\
\hline
\end{tabular}

Values are Mean \pm S.E.M. $(\mathrm{n}=6)$; ONE way ANOVA followed by Dunnet comparisons test Significance values are ${ }^{* * *} \mathrm{p}<0.001,{ }^{* *} \mathrm{p}<0.01,{ }^{*} \mathrm{p}<0.05$ and $\mathrm{ns} \mathrm{p}>0.05$ TAA group vs all groups.

\section{5. Histopathological Studies (Tabulated in Figure 1):}

The protective effect of LCBE was further confirmed by histopathological examination of liver.

1) Normal control treatment: Sections studied show structure of liver. Architecture is normal. Central vein, sinusoids and hepatocytes are normal.

2) Thioacetamide treatment: Sections showed marked necrosis and inflammatory cell infiltration in the centrizonal area. Inflammatory cells were also observed in the portal triad. Development of fibrosis septae was observed between central veins and portal traid. 
3) Silymarin + TAA treatment: Sections studied shows structure of liver .The architecture is maintained. There is mild congestion and portal triaditis and inflammatory cells were observed in the centrizonal area.

4) LCEE (400 mg/kg) + TAA treatment: Sections studied Showed greater reduction of the necrosed area and sparse inflammatory cell infiltration around the central vein showing regeneration of hepatocytes.

5) LCEE (200 mg/kg) + TAA treatment: Sections studied show liver has not damaged architecture, most of central veins showed congestion of sinusoids. Inflammatory infiltration observed within hepatocytes.

6) LCAE (400 mg/kg) + TAA treatment: Sections studied show structure of liver parenchyma with partial architecture showing regeneration of hepatocytes.

7) LCAE (200 mg/kg) + TAA treatment: Sections studied show liver has not damaged architecture, most of central veins showed congestion of sinusoids. Inflammatory infiltration observed within hepatocytes.

8) LCAE + LCEE (400 mg/kg) + TAA treatment: Sections studied Showed greater Reduction of the necrosed area and sparse inflammatory cell infiltration around the central vein showing regeneration of hepatocytes.

9) LCAE + LCEE (200 mg/kg) + TAA treatment: Sections studied showed reduction of necrosed area and inflammatory infiltrates in the centrizonal area along with regeneration of hepatic cells and sinusoids.

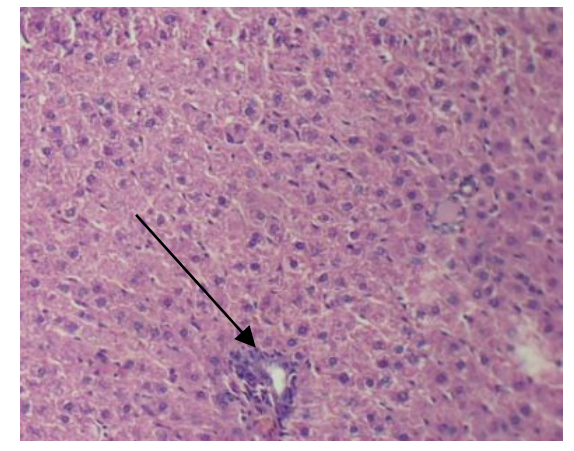

Normal Group

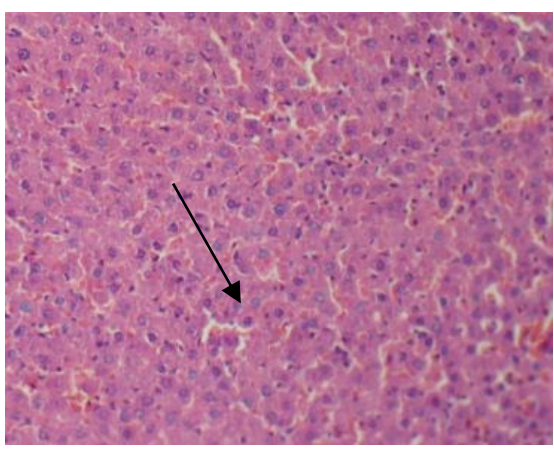

Treated With Silymarin

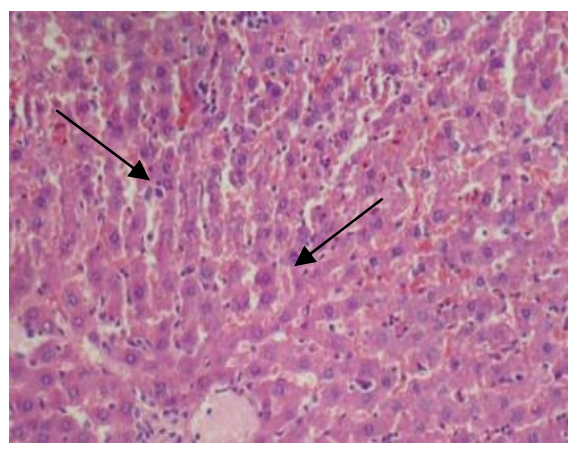

Treated With TAA

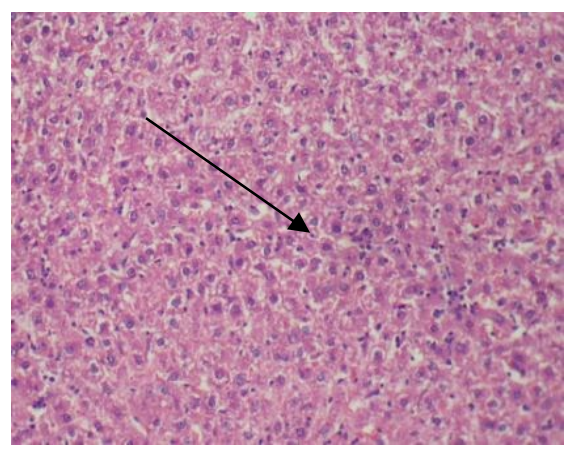

LCEE (400 mg/kg)

Fig. 1. Histopathological studies of the rat liver in thioacetamide induced hepatotoxicity. Magnification (X 100). 


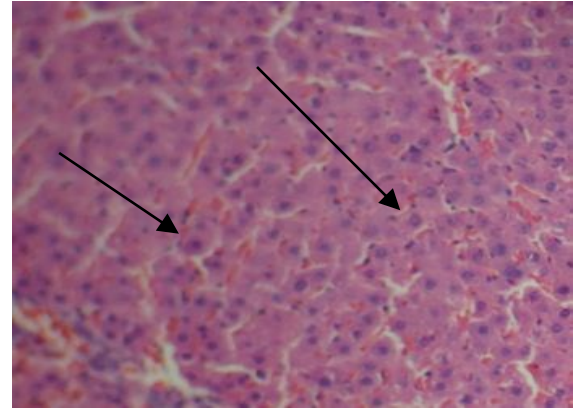

LCEE $(200 \mathrm{mg} / \mathrm{kg})$

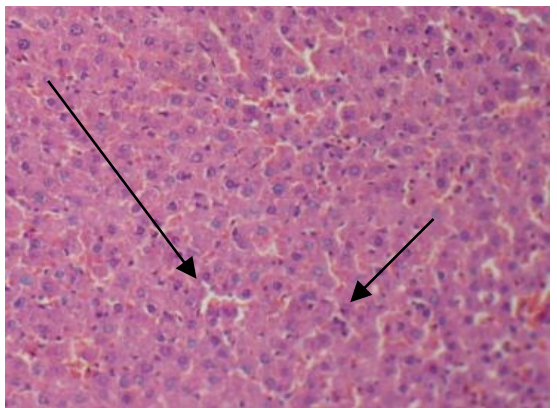

LCAE $(200 \mathrm{mg} / \mathrm{kg})$

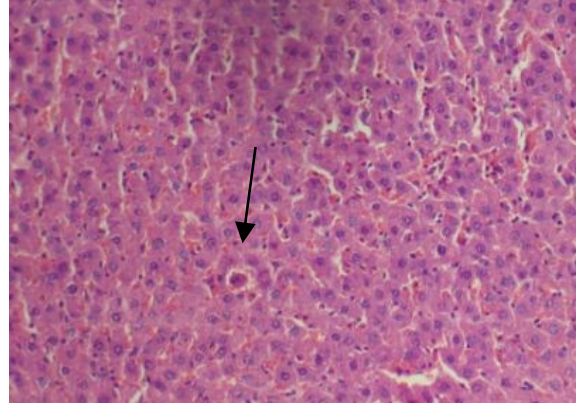

LCAE $(400 \mathrm{mg} / \mathrm{kg})$

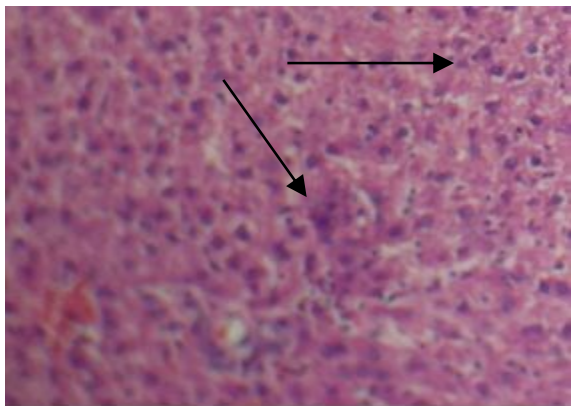

LCAE + LCEE $(400 \mathrm{mg} / \mathrm{kg})$

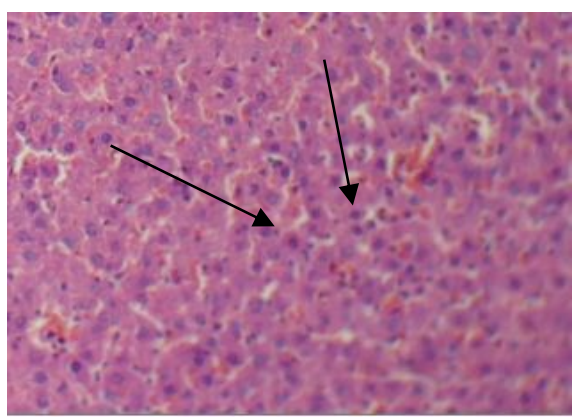

LCAE + LCEE $(200 \mathrm{mg} / \mathrm{kg})$

Fig. 1(continue). Histopathological studies of the rat liver in thioacetamide induced hepatotoxicity. Magnification (X 100).

\section{6. Antioxidant activity}

\section{DPPH method for antioxidant study}

The percent inhibition of 1, 1-diphenyl-2-picrylhydrazyl (DPPH) radical with different extracts of Lannea coromandelica has depicted in below table (3) along with the standard Gallic acid curve (Figure 2).

Table 3. Antioxidant study of LCBEs by DPPH method.

\begin{tabular}{|c|c|c|c|c|}
\hline S1 No. & Extracts & $\begin{array}{c}\text { Conc. of extracts } \\
(\mu \mathrm{g} / \mathrm{ml})\end{array}$ & \% Inhibition & $\begin{array}{c}\mathrm{IC}_{50} \\
(\mu \mathrm{g} / \mathrm{ml})\end{array}$ \\
\hline \multirow{2}{*}{1} & \multirow{2}{*}{ Gallic acid } & 0.5 & 14.92 & \multirow{2}{*}{$1.95 \pm 1.10$} \\
\cline { 3 - 4 } & & 1.5 & 33.48 & \\
\hline
\end{tabular}




\begin{tabular}{|c|c|c|c|c|}
\hline \multirow{2}{*}{2} & 2.5 & 53.69 & \multirow{2}{*}{8} \\
\cline { 3 - 4 } & \multirow{3}{*}{2} & 5 & $30.21 \pm 1.28$ & \multirow{2}{*}{$196.20 \pm 4.31$} \\
\cline { 3 - 4 } & \multirow{2}{*}{3} & 50 & $41.39 \pm 1.42$ & \\
\cline { 3 - 4 } & \multirow{2}{*}{ LCAE } & 100 & $45.31^{\mathrm{a}} \pm 2.16$ & \multirow{2}{*}{$134.52 \pm 4.11$} \\
\cline { 3 - 4 } 4 & \multirow{2}{*}{4} & 50 & $47.16^{\mathrm{a}} \pm 2.10$ & \\
\cline { 3 - 4 } & LCAE + LCEE & 100 & $53.72^{\mathrm{a}} \pm 1.20$ & \multirow{2}{*}{$83.28 \pm 2.12$} \\
\cline { 3 - 4 } & extract & 50 & $54.23^{\mathrm{a}} \pm 1.12$ & \\
\hline
\end{tabular}

- All values are means of triplicate determinations \pm standard deviation (SD).

- Means within columns with different letters are significantly different $(\mathrm{P}<0.05)$.

- $\mathrm{IC}_{50}$ : Concentration required for $50 \%$ inhibition.

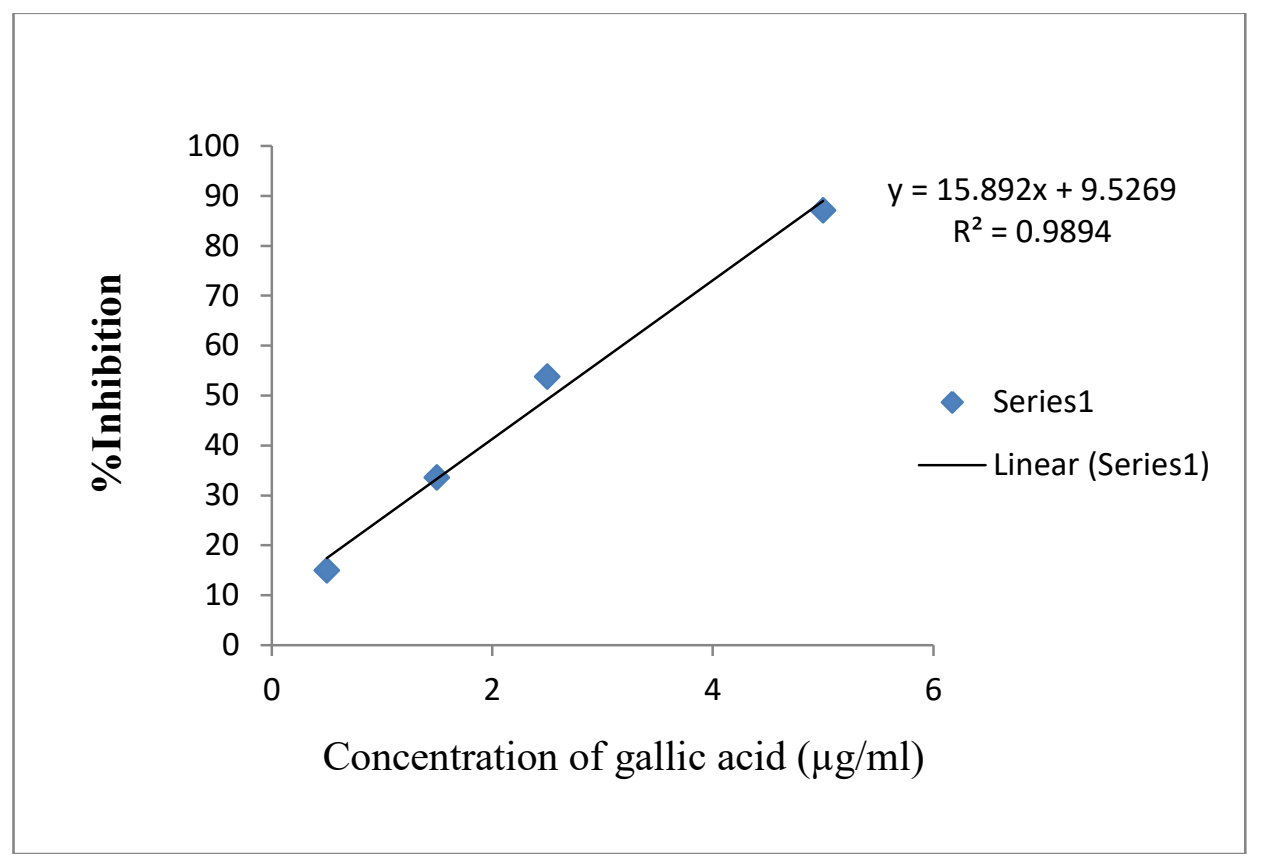

Fig. 2. Standard curve for Gallic acid at different concentration.

\section{DISCUSSION}

\section{1. Hepatoprotective activity}

In living system liver is considered to be highly sensitive to toxic agents. It's also one of the hardest working and can even re-grow its own tissue. It can work when a large portion of it is removed or diseased. It participates in a variety of metabolic activities perhaps by virtue of presence of number of enzymes and thus may self expose too many toxicants, chemicals and drugs which could injure it [14]. In our hepatoprotective study, TAA was used as hepatotoxicants to induce liver damage, since it was reported that a single dose of this 
hepatotoxic agent could produce centrilobular hepatic necrosis and that chronic administration led to cirrhosis and hepatocarcinoma. Chronic TAA exposure produces cirrhosis in rats. TAA needs to be activated metabolically for its effect to be toxic that is metabolized by liver CYP 450 2E1 enzymes rendering products of its metabolic transformation include acetamide, sulphate, TAA sulphoxidesulfone and sulfoxide [15] derivatives which are apparently responsible of structural proteins and enzymes inactivation. The toxic effect of thioacetamide is attributed to the latter metabolite Thioacetamide may increase the synthesis of fatty acids and decrease the release of hepatic lipoproteins. The thioacetamide-5- oxide is responsible for the change in cell permeability, increased intracellular concentration of calcium, increase in nuclear volume and enlargement of nucleoli and also inhibits mitochondrial activity which leads to cell death [16]. Besides, TAA toxicity mechanism was related to alteration in NADPH - Cytochrome $\mathrm{P}_{450}$ reductase activity and to nitric oxide synthesis. The hepatocellular metabolism of potent inflammation mediators, such as the leukotrienes, is also impaired in TAA - induced hepatotoxicity [17].

\section{2. Biochemical parameters}

\section{2. 1. Estimation of serum marker enzymes}

Estimation of serum marker enzyme is a useful quantitative marker of the extent and type of hepatocellular damage. During hepatic damage, cellular enzymes like AST, ALT and ALP present in the liver cells leak into the serum that resulting in increased concentrations.

SGPT or ALT (Alanine transminase) is a cytosolic enzyme primarily present in the hepatocytes. The level of SGPT in serum increases due to leakage of this cellular enzyme into plasma by TAA induced hepatic injury. SGOT or AST (Aspartate transaminase) is a mitochondrial enzyme presents in liver paranchymal cells released from heart, liver, skeletal muscle and kidney. Liver toxicity elevated the SGOT levels in serum due to the damage to the tissues producing acute necrosis. The oxidative stress was linked in elevation of transaminases in plasma and serum. Serum alkaline phophatase (ALP) is an enzyme in cell lining the biliary duct of liver. ALP levels rised in plasma because of large bile duct obstruction by TAA induced oxidative stress [18]. The results of biochemical parameters revealed the elevation of all the enzymes level in TAA treated group, indicating that TAA induces damage to the liver (Table 1,2). After treatment with Lannea coromandelica extracts, there was a significant reduction observed in ALT, AST and ALP showing dose dependent activity where LCEE high dose and LCAE + LCEE high dose was highly significant followed by LCAE Showed less activity compared to other to extracts. The enzyme levels were almost restored to the normal which is an indicative of hepatoprotective activity.

\section{2. 2. Direct and Total bilirubin}

Bilirubin is a break down product of heam (a part of haemoglobin). The liver is responsible for clearing the serum bilirubin. In this mechanism bilirubin is taken up into hepatocytes, conjugated (modified to make it water soluble), and secreted into the bile, which is excreted into intestine. Total bilirubin includes both direct (conjugated) and indirect (unconjugated) bilirubin. In the progressive liver injury from necrosis to cirrhosis, reduces bilirubin metabolism (reduction in hepatocyte uptake, impaired conjugation of bilirubin and reduced hepatocyte secretion of bilirubin). Decreased level of serum bilirubin [19] after treatment with Lannea coromandelica extracts indicates the effectiveness in normalizing the functional state of liver. 


\section{2. 3. Total protein and total albumin}

The liver produces most plasma proteins in the body. Being a part of cell membrane and as an enzyme, protein participate the intricately balanced subcellular fractions. Protein plays a major role in the synthesis of microsomal detoxifying enzymes and helps to detoxify the toxicants which enter into the animal body [20]. TAA induced liver toxicity decreases the total protein and albumin level in serum due to damage to the tissues. After treatment with Lannea coromandelica extracts there was increase in serum protein and albumin level indicating plants hepatoprotective activity.

\section{2. 4. Effect on Sodium and Potassium concentration}

The $\mathrm{Na}^{+}-\mathrm{K}^{+}$pump is found in the membranes of many types of cells. This pump illustrates "active transport" since it moves $\mathrm{Na}^{+}$and $\mathrm{K}^{+}$against their concentration gradients. Since the pump requires an ATP every time it works ATP is created during the processes called cellular respiration, Part of cellular respiration happens in the cytoplasm, and part in the mitochondrion.

Pathological processes that interfere with the production of ATP may interfere with sodium pump activity, which in turn results in decreased hepatocellular function, the hepatocyte membrane appears to be the critical locus of damage and oxidative alterations are responsible for membrane damage in TAA-induced hepatotoxicity in rats [21]. Treatment with LCBE elevated the sodium and potassium level, which was decreased due to TAA induced liver damage. Thus, indicating the hepatic regeneration and membrane stabilizing activity of the extracts.

\section{3. Histopathological studies}

Histopathological examination of liver section of vehicle control group showed normal cellular architecture with distinct hepatic cells, sinusoidal space .In the liver section of rats intoxicated with thioacetamide $(100 \mathrm{mg} / \mathrm{kg})$ there is disarrangement and degeneration of normal hepatic cells characterized by congestion, vacuolar degeneration, necrosis, and inflammatory cell collections with intense centrilobular necrosis and destruction of central vein. While rats treated with Silymarin showed prominent central vein less disarrangement and degeneration of hepatocytes.

The liver section of rats treated with two different doses $(400 \mathrm{mg} / \mathrm{kg}$ and $200 \mathrm{mg} / \mathrm{kg})$ of Lannea coromandelica extract showed regeneration of central vein and less disarrangement of hepatocytes in LCEE high dose and LCAE + LCEE high dose extracts when compared with TAA intoxicated rats whereas LCEE low dose LCAE high dose and LCAE + LCEE low dose showed inflammatory infiltrates in the centrizonal area and portal triaditis with mid necrosis indicating slow regeneration of hepatocytes.

Liver protective herbal drugs contain a variety of chemical constituents like phenols, coumarins, lignans, essential oil, monoterpenes, carotinoids, glycosides, flavonoids, organic acids, lipids, alkaloids and xanthenes [22]. Phytochemical evaluation of Lannea coromandelica revealed the presence of vitamins, minerals, amino acids, Flavonoid, unsaturated Sterol, triterpene, tanninbetacyanins and polyphenols in LCEE, LCAE and LCAE+ LCEE extracts. In the present investigation, the hepatoprotective activity can be due the presence of amaranthin, betacyanins, flavonoids and other chemical constituents which are potential antioxidants present in the extracts may have attributed to protect against hepatic oxidative stress [23], or could be by the stimulation of hepatic regeneration [24] through an improved synthesis of protein or accelerated detoxification and excretion. 


\section{4. Antioxidant study by DPPH method}

Compare to the commercially available organic nitrogen radicals, DPPH is one of the stable radical. This assay is based on the proportional antioxidant effect to the disappearance of DPPH in test samples. A freshly prepared DPPH solution exhibit a deep purple color with absorption maximum at $517 \mathrm{~nm}$. The purple color generally fades or disappears when an antioxidant is present in the medium. Results were reported as $\mathrm{IC}_{50}$, which is the amount of antioxidant necessary to decrease the initial DPPH concentration by $50 \%$. The lower the IC50, the higher is the antioxidant power. LCAE and LCEE in combination showed lowest $\mathrm{LD}_{50}$ followed by LCEE due to presence of phenolic constituents [25]. This indicates LCBE significantly reverse these toxin induced changes. Since, these are cytosolic enzymes, which get released into the serum as a result of damage to the cell membrane of hepatocytes. Hence a reduction in the levels of these enzymes demonstrates membrane stabilizing activity of the whole plant.

\section{CONCLUSION}

The bark extracts of Lannea coromandelica have shown very significant hepatoprotection against TAA-induced hepatotoxicity in rats in reducing serum total bilirubin, ALT, AST and ALP levels. It was also found that among the extracts high doses of LCEE and LCAE + LCEE showed significant higher activity than others but the results were dose dependent. Hence it can be concluded that Lannea coromandelica have potential hepatoprotective activity and attenuates the hepatotoxic effects of TAA by membrane stabilizing effect and acting as an antioxidant that may be due to presence of flavonoids, tannins and phenol.

\section{Acknowledgement}

Authors are thankful to Guruprasad Suttur, M. Pharm student, Dept of Pharmacology, St. John's Pharmacy College for isolated organs for histopathological study. Further extended thanks to the Principal of St. John's Pharmacy College, Bangalore for facilities provided to carried out the present study.

\section{Biography}

V. Srinivasa Rao: He was a M. Pharm student in Dept. of Pharmacology, in St John's Pharmacy College, Bangalore. He is working presently in Andhra Pradesh as an Asst. Professor.

Mr. John Wilkin Einstein: He is the main supervisor for this work. He has designed the work and advised to Srinivasa Rao to carry out the experiment. He is having more than 6 international research papers and pursuing $\mathrm{PhD}$ from University of Malaya, Malaysia. He is having number of oral and poster presentations and guided more than $08 \mathrm{M}$. Pharm students.

Dr. Kuntal Das: Presently working in Krupanidhi College of Pharmacy, Bangalore. He is a co guide for this experiment. He is having more than 40 research papers and more than 10 presentations national and Internation level. He also authored 3 books and 4 book chapters and has co-guided more than $10 \mathrm{M}$. Pharm students. He is active reviewer and editor board member in many national and International journals. 


\section{References}

[1] F. M. Ward, M. J. Daly, Churchill Livingstone, New York, (1999) 195-212.

[2] B. Sharma, U. K. Sharma, Int. J Pharm Tech Res 1 (2009) 1330-34.

[3] M. S. Akhtar, M. Amin, M. Ahmad, Ethnobotanical Leaflets 13 (2009) 310-15.

[4] P. G. Pearson, L. C. Wienkers, Handbook of Drug Metabolism (2009) 64-69.

[5] G. M. Cragg, D. J. Newman, K. M. Snader, Journal of Natural Products 60 (1997) 5260 .

[6] S. A. Ali, T. H. Al-amin, A. H. Mohamed, A. A. Gameel, J. Pharmacol and Toxicol 4 (2009) 167-72.

[7] A. Bahar, A. Tanveer, A. K. Shah, J ethnopharmacol 76 (2001) 187-189.

[8] M. Yusuf, J. Begum, M. N. Hoque, J. U. Chowdhury, Bangladesh Council of Scientific and Industrial Research (2009).

[9] M. T. Islam, S. Tahara, Phytochemistry 54 (2000) 901-907.

[10] G. Pandeya, Chaukhambha Sanskrit Sansthan (1997).

[11] C. K. Kokate, Practical Pharmacology 4 (1996) 107-112.

[12] S. K. Ashok, S. N. Somayaji, K. L. Bairy, Indian J. Ppharmacol 32 (2001) 260-266.

[13] S. Baros, M. Karsayova, K. Jomova, A. Gaspar, M. Valko, Journal of Microbiology Biotechnol Food Sci 1 (2012) 725-732.

[14] G. Kumar, G. Sharmila Banu, P. Vanitha Pappa, M. Sundararajan, M. Rajasekara Pandian, J Ethnopharmacol 92 (2004) 37-40.

[15] B. Jayaprakasam, Y. Zhang, M. G. Nair, J. Agric. Food Chem 52 (2004) 6939-6943.

[16] T. Vani, M. Rajini, S. Sarkar, CJ. Shishoo, Int. J. Pharmac 35 (1997) 313-317.

[17] B. Auddy, M. Ferreira, F. Blasina, L. Lafon, F. Arredondo, F. Dajas, P. C. Tripathi, T. Seal, B. Mukherjee, J. Ethnopharmacol 84 (2003) 131-138.

[18] P. Kumar, G. D. Rao, S. R. Setty, Pharmacologyonline 3 (2008) 181-189.

[19] C. K. Roy, J. V. Kamath, M. Asad, Ind J Exp Bio 44 (2006) 35-41.

[20] T. Kelly, GUT 27 (1986) 339-349.

[21] E. I. Rubin, Essential pathology, Lippincott Williams \& Wilkins 14 (1995) 393-440.

[22] S. K. Mitra, M. V. Venkataranganna, R. Sundarin, S. Gopumadhavan, J Ethnopharmacol 63 (1998) 181-186.

[23] M. Muthulingam, P. D. Savio, T. S. Seeli, N. Indra, S. Sethupathy, Int J Cur Res 5 (2010) 41-46.

[24] V. Nikolaev, M. Kerimova, E. Naydenova, E. Ivanov, D. Adjarov, Toxicol 48 (1988) 81-85.

[25] M. Hajimahmoodi, N. Sadehi, B. Jannat, M. R. Oveisi, S. Madani, J Biol Sci 8(2008) 779-783. 